\title{
Pedagogical violence
}

Eugene Matusov, University of Delaware, USA*

Paul Sullivan, University of Bradford, UK

*Corresponding author:

School of Education

University of Delaware

Newark, DE 19716

ematusov@udel.edu

+1 (302) 831-1266 (phone)

+1 (302) 831-4110 (fax) 


\title{
Pedagogical violence
}

\begin{abstract}
In this paper, we consider the phenomenon of "pedagogical violence" - infliction of physical, social, emotional, or psychological pains, or threat of such pains that is either the means for or non-accidental by-products of education used on a systematic basis. Pedagogical violence is often used for promoting certain desired learning in students. Alternatively, it can emerge as a violent reaction in students and teachers to particular educational settings directed against other students or teachers. In this paper, we review some of the debates and controversial issues around pedagogical violence, and we use a variety of illustrative examples to explore in more detail what pedagogical violence means in particular contexts. We argue that pedagogical violence is a natural consequence of alienated instrumental education. We will look at teachers' desire to avoid physical and psychosocial pedagogical violence. We specifically consider diverse forms of psychosocial pedagogical violence and its issues such as: summative assessment, epistemological pedagogical violence, students' ambivalence around pedagogical violence, rehabilitating/avoiding pedagogical violence through a carnival. We finish with a reflection about what can be done to minimize pedagogical violence. Our analysis heavily relies on the Bakhtinian theoretical framework of critical ontological dialogism.
\end{abstract}

\section{Acknowledgements}

We want to thank our colleagues Ana Marjanovic-Shane, Mark Smith, Robert L. Hampel, and John Ackroyd, for providing critical feedback, terrific suggestions, and editing for earlier versions of the paper.

\section{Pedagogical violence}

\section{Epigraphs}

"I believe behavior comes before learning" The head of a high school science department in one of US schools, 2016

"Although teachers do care and do work very, very hard, the institution is psychopathic - it has no conscience. It rings a bell and the young man in the middle of writing a poem must close his notebook and move to a different cell where he must memorize that humans and monkeys derive from a common ancestor."

John Taylor Gatto ${ }^{1}$

\section{Introduction}

The concept of "pedagogical violence" is unfortunately not a new one. While we would like to think that the term "pedagogical violence" is an oxymoron, it is established through the literature that it

${ }^{1}$ https://en.wikipedia.org/wiki/John Taylor Gatto 
is instead almost a tautology, with violence endemic in the concept of pedagogy. Freire's (1970) "pedagogy of the oppressed" opened our eyes to the linkage between pedagogy, oppression, and violence with his distinction between dialogue (for Freire - open and voluntary social organization) and anti-dialogue (manipulation, violence, coercion) to move towards a non-violent pedagogy.

Since Freire, many others have also drawn attention to the concept of violence in pedagogy but Foucault (1995), Bourdieu and Passeron (1990), and Worsham (1998) provide us with the first clear exposition of the term "pedagogical violence," by drawing a relationship between the "pedagogical violence" of the institutional, bureaucratic pedagogical system, subjugation and the emotional life that is organized by such pedagogy. Pedagogical violence occurs when teachers, parents, other students, or school bring intentionally or unintentionally psychological or physical pains (including threats of pains) in a student to promote the student's important learning. Probably the best example of pedagogical violence is school corporal punishment - once ubiquitous now disgraced and fading gradually away around the globe ${ }^{2}$. However, as we show in our paper, although physical pedagogical violence has been gradually fading, it has been replaced with everyday psycho-social and relational pedagogical violence.

Pedagogical violence is often justified by a belief that in the long run, the student will appreciate this pain as necessary and even desirable, which essentially establishes the teacher-student "sadomasochistic" relationship. We use the qualifier "sadomasochistic" as a literary metaphor of a pedagogical ideology justifying pedagogical violence rather than to refer to a psychological phenomenon, although at times, it can include literal enjoyment or, at least, appreciation of violence for some participants. According to this ideology, a good teacher should strive for inflicting effective, justified, and necessary pedagogical violence (i.e., pedagogical "sadism") and a good student should greatly appreciate it as it leads to his/her learning to be appreciated now or in the future (i.e., pedagogical "masochism"). Linguists have established that the etymology of the majority of educational terms in diverse languages often refers to some level of pedagogical violence, whereby a teacher violently imposes on a student something that the student may not wish to do on his or her own; "the root of the [Hebrew] word for teach/learn (דמל) coincided with that for the goad, specifically the one used to prod cattle" (Moore, 2009, p. 422).

Pedagogical non-negotiable imposition is arguably the heart of modern conventional institutionalized education (Matusov, 2015). It probably comes from a deep-rooted societal conviction that since by definition a student is one who is ignorant and inept, the student cannot define and shape her or his own education - education must be imposed on the student without any negotiation. Many students, especially young ones, do not choose whether to engage in education or not -education is imposed on them. Many students do not choose what to study - the curriculum is imposed on them. Many students do not choose what educational activities to experience - the assignments are imposed on them. Many students do not choose to ask their teachers for help - the guidance is imposed on them. Many students do not choose to be around other students or particular teachers - the peers and the teachers are imposed on them. Many students do not choose a particular place and time to studythe time-space is imposed on them. Many students do not choose particular ways of communication and participation in the classroom (or even whether to communicate or participate) - the particular ways of communication and participation are imposed on them. Many students do not choose to expose their work or study for the teacher's assessment - the assessment is imposed on them. In short, most students do not have any voice about their education. The students are expected to submit their will,

${ }^{2}$ https://en.wikipedia.org/wiki/School corporal punishment 
desire, heart, mind, feelings, behavior, and attitudes for non-conditional cooperation with the teachers', schools', and test makers' demands. Teachers, schools, adults, and, finally, society know best what is good for the ignorant and inept students. When students successfully finish their institutionalized education, they are expected to appreciate this education, and these non-negotiable forcible often painful impositions.

As this conviction goes, left to their own devices, many students may not choose education for themselves at all, but even those who may choose, may not choose proper education, proper curriculum, and proper instruction. Thus, education has to be forced on the students, and this use of force has to be backed up with violence - i.e., measured applications of pains. Arguably, this may come from "a religious custom of telling the congregation of what they should and should not do. The widespread conviction that teaching is about telling, learning is about listening, and knowledge is about clear-cut factual information owes a great deal to the history of religion" (Robert L. Hampel, personal communication, January 23, 2017).

In our paper, we want to consider reasons, justifications, and conditions for pedagogical violence, its types, its spread and trends, its link with pedagogy, and the issue of its desirability and unavoidability in education.

\section{What is pedagogical violence?}

In an excellent essay on violence, Graeber (2015) makes the point that bureaucracies (a system of rules, procedures) have violence at their heart, insofar as rules and procedures can ultimately only be enforced by violence, including its threat, by suppressing any dissent, incompliance, or resistance. In modern bureaucratic societies, behind rules, regulations, procedures, court decisions, and laws there hovers "soft violence" in its shadow. Soft violence is based on the infliction of psycho-social and relational pains of eviction, exclusion, ostracism, arrest, imprisonment, fines, and so on. However, as Graeber argues, behind "soft violence" there hovers the shadow of "hard violence" of physical pains administrated by police, army, and guards (cf. Foucault, 1995). The bureaucratic system itself is blind to "value" or "stupidity" but enforces the rules of whatever the system demands through recourse to violence or the threat of violence - or various means of manipulation, "Violence's capacity to allow arbitrary decisions, and thus to avoid the kind of debate, clarification, and renegotiation typical of more egalitarian social relations, is obviously what allows its victims to see procedures created on the basis of violence as stupid or unreasonable" (Graeber, 2015, p. 66). In rule-following and form-filling, bureaucracy renders people who disagree with it "stupid" and is ultimately able to enlist officials (e.g. the police, state bureaucrats, or psychiatric nurses) to use physical force to ensure compliance.

Although Graeber does not discuss pedagogy, he helps to make sense of how teachers/professors can be viewed as bureaucrats rather than pedagogues. Graeber also argues that the police are bureaucrats who enforce bureaucratic rules such as driving rules and only rarely get directly involved in violence, perhaps when there is paperwork involved or when their position is questioned by a dissenter. Under similar logic, despite the abstract value of an authentic love of learning in teaching, teachers are supposed to teach and many do teach their students the practice of following arbitrary rules (bureaucracy) for instrumental ends (e.g., money, good grades, parents' approval, high test scores, getting institutional credits and credentials, access to desired jobs and institutions), underpinned by the threat of violence - usually soft violence.

Over-assessment and testing regimes, based on the behaviorist reward-and-punishment system, teach students how to work without meaning. The students' work outcomes (or homework) can be 
simply thrown away because it does not have any "use-value" for the students or the teachers (see Sidorkin 2002). Both corporate and public bureaucracies demand from the students much meaningless and unimaginative work. There is only limited scope for "imaginative labor" in society - e.g., organizing the means of production or creative problem defining/solving, - which disproportionately goes to managerial and professional elites.

The mass education system is more useful for a training in a labyrinthine of bureaucracy (e.g., following prepared scripts in call-centers, working on a production line, marking scripts according to a rigid set of the marking grade criteria), with rarely tested values at their heart, and with a threat of violence as the means of compliance. As we will discuss later, this may change with the advent of technology, but for now, vast swathes of the workforce work in strict rule-following jobs such as callcenter work. Bertrand Russell told in a letter to a friend of his experiences as a visiting academic at Harvard in 1914. He wrote that the atmosphere among scholars there encouraged "quick results, efficiency, success - none of the lonely hours away from mankind that go to producing anything of value," and goes on to add that the professors at Harvard were "more alert and business-like and punctual than one expects very good people to be!" (Monk, 1996, p. 347) 3 .

If this is the societal context of education, then it is all the more important to reflect on the role of violence in sustaining this education (non-voluntary, unconditional cooperation with educational authorities) and to examine ways in which it may be creatively dialogued with.

In our classification, the nature of the pains/pedagogical violence can have diverse aspects and which is worse depends on the laws of a particular society (e.g., corporal punishment is still legal in Singapore, Malaysia, Middle-East) and some private schools in the West (e.g., Australia) while more subtle forms of punishment are available more generally in the English speaking world. To make a tentative list of the everyday forms of pedagogical violence available: physical (e.g., beating - corporeal punishment), physiological (e.g., making student starve), psychological (e.g., humiliation, shaming), social (e.g., ostracism, public humiliation, scapegoating, exclusion, disrupting parent-child relations), emotional (e.g., making student depressed), economic (e.g., withholding economic opportunities or resources from a student), institutional (e.g., denying access to a desired institution or an institutional practice), sexual (e.g., harassment, rape, exchange of good grades for sex), epistemological (e.g., exposure a student to painful ideas or learning activities), and so on. Some of these forms of pedagogical violence are institutionally and societally legitimate (e.g., shaming, lawful school corporal punishment, denying access to a desired institute, disrupting student-parents relationships), some not legitimate at all (e.g., rape, scapegoating, unlawful beating), and some in-between (e.g., making students depressed, humiliation). In our view, pedagogical violence can be achieved by diverse means: corporal punishment, low grades, suspension, expulsion, withdraw of recommendation, reporting to parents, yelling, sarcasm, sexual harassment, cutting recess time, withdraw of relationship, disrupting relationship with peers and/or parents, referral to the principal, giving assignments, separating friends, and so on. Again some of these means are viewed by the society and institutions as legitimate, some illegitimate (if not even criminal), and some are in-between. We will consider examples of pedagogical violence that are currently viewed as legitimate by the society below. These various pains, including physical, are always psychological in their nature to be effective and may even lead to dysconscious awareness of the pedagogical violence (Sihra \& Anderson, 2010). "Dysconsciousness" refers to an uncritical acceptance of inequality (or pedagogical violence as it is in our case) as given, necessary, and unchangeable.

\footnotetext{
${ }^{3}$ We are thankful to John Ackroyd for providing this quote.
} 
Of course, not all violence that occurs in schools is necessarily pedagogical, and pedagogical violence can occur outside of school. For example, some personal fights and bullying that occur in school may not be pedagogical in its nature because the school context may be accidental to the violence. Personal violence among students may not be pedagogical if it is not used to submit the students to unconditional educational cooperation. On the other hand, parents may inflict pedagogical violence on their children (e.g., by forcing homework, teaching reading, toilet training) even outside of school.

Some non-pedagogical violence can be a by-product of the rigid and unilateral organization of conventional educational institutions violating human ecology and human freedoms (e.g., forced participation, school/classroom crowdedness). This type of violence can emerge in educational settings as a result of violation or neglect of human ecology and not necessarily a means or a result of pedagogical imposition. Conventional schools are often very crowded spaces with regimented time, assigned activities, and forced collectivity that do not allow much for students' (and teachers') initiative, creativity, voluntary segregation, mobility, negotiation, choice-making, non-participation, and flexibility. A conventional teacher is often caught in (or thrown into) a "kaleidoscopic" type of instructional environment in which the teacher cannot easily discern the events which take place therein (Jackson, 1968). Often the primary task that many conventional teachers experience is to establish, manage, and negotiate their unilateral control over their students through "defensive teaching" (McLaren, 1993; McNeil, 1986; Sidorkin, 2002). It is often insensitive to the needs of its participants. Some aspects of the organization of the conventional educational practices put students in the relationship of competition among each other for the teacher's attention, public class floor, grades, praises, and so on. Conventional school ecologies and organization may generate "natural" tensions and micro- and macro-aggressions leading to pedagogical violence as a response to these tensions and non-pedagogical violence.

It is important to mention that pedagogical violence affects different social groups differently. It may have additional, secondary functions beyond ensuring students' unconditional cooperation with the teachers' and school's pedagogical demands. Pedagogical violence may help domesticate, colonize, and sort "wild" students who do not fit well the feminized white middle-class school institutional environment - working-class, minority (especially African American in the US), disabled, and males. Sociologists have documented the use of such pedagogical violence among working-class students (Willis, 1981) and involuntary minorities ('e.g., "acting white" phenomenon among some African American students, Fordham \& Ogbu, 1986) but it is not limited to these social groups.

Finally, some pains and discomforts rooted in learning may not be pedagogical in their nature. For example, pains rooted in athletic sport drills or intellectual challenges and frustrations may not be a result of pedagogical violence because they do not necessarily involve the student's submission to the teacher's pedagogical desires.

\section{Physical pedagogical violence: disciplining the student's body}

In the past, pedagogical violence was mostly physical in its nature. Thus, it was reported that famous Russian tsar Peter The Great liked to learn diverse practices like smithcraft, shipbuilding, and so on. He signed himself into such practices as a common apprentice at various enterprises in Russia and Europe. Often, he was beaten (e.g., slapped) or verbally scolded by his impatient masters for mistakes he made. However, he did not punish the masters but rather replied, "Thanks for teaching me!" (“Благодарю за науку!", literally in Russian, "Thanks for science!”). In addition to physical pain, psychological pain was used by parents for teaching their children character, morals, and discipline. The transgressing children were often sent into the woods to find a rod for their disciplinary beating, for which the children had to thank the parent (usually the father) for administrating this corporeal 
punishment. Children were expected to be thankful for the pain-induced learning that their parents caused in them, which is well articulated in the famous English sayings, like "Spare the rod, spoil the child," "No pain - no gain!" As Henderson suggests in Saul Bellow's Henderson, The Rain King, "Truth comes in blows" (Bellow, 1996) or as Salisbury (2004) remarks with regard to medieval education:

The schoolmaster's commands, admonishments, and directives accompanied by a blow with a rod encourages the student to associate the master's word with the blow until eventually the word and the blow become one (p.145).

In most countries, school-induced corporal punishment - official physical punishment for students' noncooperation with the educational institutional demands - has been legally banned from schools by the end of the $20^{\text {th }}$ century with a striking exception of the United States, where it still has remained legal in 19, mostly southern, states and in 2 states it is legal only in private schools (New Jersey and lowa $)^{4}$. School corporal punishment has involved the infliction of physical pain that is often accompanied by social, emotional, and psychological humiliation, social ostracism, and psychological distress. The primary purpose of school corporal punishment, in our view, is to drastically achieve the conformity of students with the school norms, goals, actions, and requirements.

However, at times, corporal punishment is a response to a bad, unsafe, ecology in which adults find themselves in with children. Thus, parents living in dangerous and unforgiving environments apply corporal punishment to their children often to make them avoid social and physical dangers, hardships, and risks as well as out of parental helplessness, irritation, and desperation (Freire, Freire, \& Freire, 1994; Lareau, 2003). It has often been designed to have a communal effect of a threat and warning for students who might directly not be the object of school corporal punishment but who might be involved in future transgressions.

With the decline of its legality, several issues have emerged. In certain contexts, physical punishment is still acceptable, even though it is officially prohibited. Interestingly, in Japan, for example, Omi (2019) found in a survey of 110 trainee teachers that despite a legal prohibition on corporal punishment since 1941, corporal punishment in the context of bukatsu (meaning extra-curricular activity particularly sports) was experienced by just over a quarter of his sample and also accepted by $68 \%$ of these, despite their stance against corporal punishment in general. In the particular context of the rigid hierarchy of bukatsu, and the intense periods of time spent on an exclusive activity by non-trained coaches, corporal punishment is relatively normal (e.g. one story of 30-40 slaps during the day before practice).

In other contexts, 'hard' physical punishment has transformed into softer but also punishing violence. Such "softer" forms of pedagogical violence may involve verbal threat, social humiliation, referral to the principal and/or parents, detention, suspension, expulsion, punishment by assigning extra "learning" work, loosing of recess, lowering grades, and so on. There can be also illegal use of physical pedagogical violence directly by the teachers or indirectly mediated by other students. Recent brain research has found that some forms of softer violence activates the same areas of the brain as physical pains (Eisenberger \& Lieberman, 2004).

At the same time, some students may actively resist the pedagogical regime imposed on them by violent (and non-violent) means. They may attack and bully teachers and their peers physically, verbally, or virtually (via social media networks) in response to the school pedagogical regime, norms,

\footnotetext{
${ }^{4}$ http://en.wikipedia.org/wiki/School corporal punishment
} 
and demands. The students may skillfully use sarcasm, humor, taboos, teasing, laughter, pranks, hacks, shaming, and so on, as powerful weapons against their targets.

\section{Psychosocial pedagogical violence: disciplining the student's mind}

Psychosocial pedagogical violence involves inducement of psychological and social pains in students in order to ensure their unconditional cooperation with the pedagogical activities and outcomes defined, organized, and imposed by the teachers, school, and society. This is disciplining the students' minds. Psychosocial pedagogical violence may take many different forms but here we limit ourselves to considering two most common types of psychosocial pedagogical violence: summative assessment and epistemological imposition. These are of interest to us because they help reveal the prosaic everyday forms of pedagogical violence.

\section{Pedagogical violence of summative assessment (grading)}

Educational summative assessment is supposed to be an assessment of a student's competence after education has been "done." Russian American sociologist of education Pitirim Sorokin defined school as a "sorting machine" to produce a dynamic class stratification of the society (Sorokin, 1927). Summative assessment sorts people on those who will get certain personally desired goodies like access to good jobs, good educational institutions, financial aid, and so on and on those for whom these goodies will be denied. By its intentional design, summative assessment is inherently unsafe for its subjects as it may end up in losses and pains and, thus, can be violent in its nature. As a by-product of the pedagogical "soft" violence caused by summative assessment, there is a systematic production of pathologized subjectivity in academically failing students (Stojnov, Dzinovic, \& Pavlovic, 2008; Varenne \& McDermott, 1998). Thus, educational summative assessment is pregnant with pedagogical violence by its design. While the necessity of summative assessment has been widely recognized in many professions - e.g., nobody wants to have inept surgeons, airplane pilots, lawyers, teachers, politicians, and so on, - the legitimacy of summative assessment in education is questionable and contested in our view (Matusov, Marjanovic-Shane, \& Meacham, 2016). In contrast to many other practices, mistakes are valuable in education because they become teaching-learning opportunities for students and teachers. Punishing students for making mistakes - what summative assessments often does - inhibits students' learning activism and makes teaching difficult because students may try to hide from the teachers their own subjectivity: what the students think they don't know or what the students believe may not be correct from the teacher's point of view (in this vein, it is curious that efforts to bring mistakes into the open as learning opportunities within professions such as medicine are also a challenge, see Garbutt, et al., 2007). This makes the teachers' guidance insensitive as teachers may not have access to the students' subjectivity. Some educators argue that legitimate summative assessment of people's competence has to be done outside of education. By doing that summative assessment does not interfere with learning while providing legitimate gatekeeping against risky ineptitude. For example, the mastery of driving a car is summatevely assessed not by driving teachers but by the Department of Motor Vehicles. Similarly, the matery of practicing the law is summatevely assessed not by the law professors but bythe Bar Association. However, in our view, there should be a "firewall" between education and summative assessment to avoid it undermining learning, guidance, and teacher-students trust so necessary in education (Matusov, 2009).

However, educational summative assessment may have another goal and function in education, besides and beyond summative assessment of students' competence after institutional education is "done." This goal is making students comply with the teachers' and institutional non-negotiable educational demands. A colleague of mine (the first author) admitted that she administered a lot of 
consequential tests and quizzes in her classes (7-10 multiple-choice scan-ready tests/quizzes per a 1415-week semester), contributing to the final grade (i.e., summative assessment). She revealed that the primary purpose of these summative tests is to make her students come to her class meetings, take notes during her lectures, and read the assigned literature (homework). From the point of view of my colleague, most, if not all, of her students would not engage in necessary learning activities and studies on their own - the point we will return later in our paper. In her classes, summative assessment is the punishment and reward system to force the students to study. Thus, summative assessment is designed here to secure psychosocial pains in the students, who might not be obedient enough from the teacher's point of view.

Teachers often try to instill students' desire for good grades and a fear of low grades in students by reminding students about consequences of the grades on their future, by trying to incorporate grades in the students' self-esteem and identities, by creating competitions among the students for scarce good grades (e.g., so-called "grading on the curve") and/or by using grades to promote or disrupt the students' relations with their parents. As a high school student who moved from an innovative middle-school without grades to a conventional school with grades noticed,

I got really upset the other day because I was talking with one of my teachers about how grades were horrible. ... To sum it up, it was just me ranting on about how I don't like grades, and if everybody got As, there'd be no point in using the grade system, but they instituted it so people feel bad when they get a bad grade (DePalma, Matusov, \& Smith, 2009, p. 951).

However, not all students, especially working-class and minority students, care about grades, not seeing them as valuable rewards or punishments for themselves (Eckert, 1989; Willis, 1981). This forces teachers to constantly look for other means of pedagogical violence and pedagogical bribery.

Finally, summative assessment has the potential to deprive students of engaging in critical and creative thinking. It suppresses students' authorial agency and their own judgment because it is always the external agency of the test that defines the truth and not them. Summative assessment promotes what Bakhtin called "authoritative discourse" at the expense of "internally persuasive discourse" (Bakhtin, 1991). The holistic educators Sharon Solloway and Nancy Brooks argue that summative assessment in education leads to the "standardization and instrumental application of knowledge," which is "akin to violence" (Solloway \& Brooks, 2004, p. 43). Michael Strawser elaborates on why this constitutes pedagogical violence, arguing that summative assessment forces "students to think about a question in one particular way and to confine their answer, for example, to a limited number of multiple-choice or rubric options" (Strawser, 2009, p. 57). French philosopher Paul Ricœur argues that any monologizing and totalizing text (rooted in summative assessment) is based on violence to suppress alternative and challenging ideas and questions (Ricœur, 1975).

As a consequence, summative assessment in education inhibits students from reflecting on their own subordinated position in society, preventing any liberating activism on the part of the students. In part, it is because the psychological pain of summative assessment causes students to doubt themselves, to believe that they are incapable of something, and even to hate themselves. But also some students with good grades may think that they are knowledgeable when their knowledge is shallow and their subjectivity "hollowed out" (Eisenhart \& Allen, 2016). 
To link back again to our root metaphor of sadomasochism. From the Foucaultian perspective of pastoral power ${ }^{5}$ (Foucault, 1983), the self-sacrifice involved in embracing pain is bound up with the system of (self) examination or summative assessment; which could be read as a confession to the pastoral power (teacher) of one's investment in and dues paid to "the knowledge" where "the knowledge" is located in a space of pastoral power.

\section{Epistemological pedagogical violence}

Knowledge can be painful. Some educators view the pain of knowledge as evidence of deep authentic education and, thus, as a desirable instruction for students' intellectual and personal growth. This new knowledge (new epistemological vista, new paradigm) can undermine one's existing comfort, one's existing ontology, one's existential being, and even one's well-being. Consider, for example, Socrates' notion of "torpedo touch," as one of the most sophisticated epistemological pedagogical violence that was described:

Meno: If I may venture to make a jest upon you, you seem to me both in your appearance and in your power over others to be very like the flat torpedo fish, who torpifies those who come near him and touch him, as you have now torpified me, I think.

Socrates: As to my being a torpedo, if the torpedo is torpid as well as the cause of torpidity in others, then indeed I am a torpedo, but not otherwise; for I perplex others, not because I am clear, but because I am utterly perplexed myself.

Socrates: If we have made him [Meno's Slave whom Socrates just taught geometry] doubt, and given him the "torpedo's shock," have we done him any harm?

Meno: I think not.

Socrates: We have certainly, as would seem, assaulted him in some degree to the discovery of truth; and now he will wish to remedy his ignorance, but then he would have been ready to tell all the world again and again that the double space should have a double side.

Meno: True.

Socrates: But do you suppose that he would ever have enquired into or learned what he fancied that he knew, though he was really ignorant of it, until he had fallen into perplexity under the idea that he did not know, and had desired to know?

Meno: I think not, Socrates.

Socrates: Then he was better for the torpedo's touch?

Meno: I think so (Plato \& Jowett, 1937, electronic version).

We call the pain that Socrates caused by creating disorientation in the student "epistemological pain." This pain, psychological in its nature, is very real. In its extreme, epistemological pain, undermining a student's existence, may lead to suicidal thoughts in some students. This is how one of my (the first author) former students described the consequences of my Socratic teaching through "torpedo touch,"

Jane: i guess it [this dialogue] becomes obsessive such that it interferes with other aspects of life... i dunno Edward, it's so weird and hard to explain but it feels like a ball and chain like a drug or an addiction or something... maybe it's just me though? maybe i'm too sensitive? like with my lack of community behind and other [personal] issues i have in my life... [these internal

\footnotetext{
${ }^{5}$ In Discipline and Punish, Foucault argues that modern society is a "disciplinary society," meaning that power in our time is largely exercised through disciplinary means in a variety of institutions (prisons, schools, hospitals, militaries, etc.).
} 
dialogues prompted by Edward are] like all related to all this stuff... it's all so very penetrating... excuse the French, but it's like a mindfuck. because maybe it does conflate with personal issues i have, but i'm sure other people have similar issues, so some of your other students could have or could be suffering like me.... but i'm sure it's worse on grad students than undergrads... i think you are very good at asking very important and penetrating questions... and sometimes you can get people to question their existence or their ways of living or why they're doing what they're doing, etc etc... you have that blessing that is a curse maybe...

Edward [i.e., Eugene]: Of course, by now you can imagine me asking, "What is wrong with that -i.e., asking about life?"...

Jane: because i wonder if you could question someone to despair or death? (Matusov \& Brobst, 2013, p. 82, spelling is original).

Another type of pedagogical epistemological pain may involve intentional humiliation to promote desired learning in a student. For example, in accordance with this Socratic pedagogical method, a US educator Jane Elliott, famously known for her anti-racist instruction "The eye of the storm" (Infinito, 2003), humiliates a White female college student to learn about a systemic problem of racism $^{6}$. The White female student in the video does not appreciate this learning, accusing her of racism, - publically humiliated, she ran away from the classroom in tears - but her White peers seem to side with Elliott, despite the observable pains caused by Elliott in them. When we shared this video with our educationalist colleagues and students (future teachers), they were split ${ }^{7}$ on the legitimacy of using public humiliation to confront a student's hidden "racism" (some educators disagreed that the student manifested any racism in the episode). Some educators consider pains coming from epistemological violence as legitimate when it leads to the "student's growth." However, other educators argue that it can be legitimate only with the student's consensus as it was in the case of Meno (Matusov \& Brobst, 2013; Matusov, Marjanovic-Shane, \& Gradovski, 2019).

Recently, there have been debates about epistemological pedagogical violence in US colleges (Shulevitz, 2015, March 15). The debate is about whether university professors have the pedagogical right to violently disrupt the students' dearest ideas and upset their psychosocial and emotional wellbeing (Lukianoff, 2013). On the one hand, is a critical examination of students' dearest ideas and prejudices not the primary goal of a good education?! On the other hand, this good education can break the students' existential well-being. For example, one of my undergraduate students in a teacher education program (the first author) suggested our class study issues of suicide in education. However, when the class selected this topic, she asked my permission not to come to the class because of her personal traumatic experiences with suicide. The important education for future teachers that she promoted was too emotionally traumatic for her. I granted her permission (although in my classes, students always have the right not to attend a class meeting while doing learning compensations instead). I had a similar experience with a student who asked not to come to my class because we were going to discuss issues of rape. Being a rape survivor, the topic was too traumatic for her.

On the other hand, an ultra-religious teacher education student asked my permission not to attend my class on sex education. I convinced her to attend because she really wanted to teach in public schools and not in religious private schools, although the choice was always hers. I do not believe in forced education. I also believe in students' academic freedom not to learn what they do not want to

\footnotetext{
${ }^{6}$ See the video documenting Elliott's Socratic teaching on racism among college undergraduate students in the US https://www.youtube.com/watch?v=neEVoFODQOE.

${ }^{7}$ Readers can also follow the YouTube discussion below the video.
} 
learn while being informed about the consequences of their educational choices (Matusov, 2020, in press-a).

\section{Students' ambivalence about pedagogical violence}

Once I (the first author) asked my undergraduate students, future elementary school teachers if they would like to design education for themselves without being forced to study. Most (but not all!) of my students said "no" mostly because they did not trust themselves that they would study on their own. One student even insisted that if she had not forced to study, she would not have got up from her bed at all. "Many novice students became anxious about trusting themselves, if the institutional oppression suddenly disappeared, calling not having grading, 'going to the Dark Side'" (Ana Marjanovic-Shane, personal communication, 2018). Of course, it is unclear if those students' lack of educational activism, educational desire, educational will, educational agency is a result of those students' nature - even their genetic and/or culture makeup (so to speak) - or a result of the conventional educational system itself, heavily based on pedagogical violence, where for their formative 12-16 years, young people are robbed of their decision making about and ownership of their own life and education (Llewellyn, 1998; Neill, 1960).

Many students accept the "no pain, no gain" masochistic ideology of conventional schools and are proud of their own academic achievements rooted in surviving painful pedagogical violence. Wear (good) grades with pride, like soldiers proud of the scars from the battles, or like tattoos worn by the former prison inmates. Toughness of the pedagogical regime of the class - the pain and suffering it inflicts on students - can become marks for students' quality of character: endurance, academic aspiration, and status. Thus, a high school student would refuse to take a hypothetical "magic learning pill" that would make them instantaneously, effortlessly, and painlessly competent and knowledgeable in a desired practice because, "Because sports in Spain is very popular, and kids that are very good at that get a lot of respect and usually get always picked by the teams and things and if I took the pill, it would be all too easy and would not have any merit in it" (Matusov, Baker, Fan, Choi, \& Hampel, 2017, p. 471). For us, such a magic learning pill could work to good effect in the short-term - like a headache pill could cure a headache - but produce long-term problems, such as a loss of desire to love knowledge through intimate acquaintance.

Students' ambivalence about pedagogical violence creates opportunities for pedagogical abuse (including sexual abuse ${ }^{8}$ ) - and even pedagogical sadomasochism, when a teacher enjoys, or professionally learns to enjoy, causing pedagogical pains in a student, while the student enjoys, or "professionally" learns to enjoy, and appreciates the pedagogical pains inflicted on him or her by the teacher in the name of quality education. Arguably, this normative pedagogical sadomasochism is a pedagogical abuse in its own turn because, despite the consent and mutual enjoyment of the pedagogical pains, the student is deprived of genuine education that is not based on a desire to inflict (pedagogical) pains. Bourdeau would probably qualify this pedagogical sadomasochism as "symbolic violence" - "the violence which is exercised upon a social agent with his or her complicity" (Bourdieu \& Wacquant, 1992, p. 167). Symbolic pedagogical violence is rooted in the entire structure of the conventional schooling and cannot be addressed by pure enlightening the students,

Because the foundation of symbolic violence lies not in mystified consciousnesses that only need to be enlightened but in dispositions attuned to the structure of domination of which they

\footnotetext{
${ }^{8}$ E.g. see the following link on teacher sackings for this: http://www.dailymail.co.uk/news/article3834137/Female-teacher-sacked-10-month-affair-girl-student-17-father-spotted-love-bites-faces-struck-off.html
} 
are the product, the relation of complicity that the victims of symbolic domination grant to the dominant can only be broken through a radical transformation of the social conditions of production that lead the dominated to take the point of view of the dominant and on themselves (Bourdieu \& Nice, 2001, pp. 41-42).

Even more, pedagogical pain seems to become a definitional of the quality of education. For example, a faculty promotion and tenure committee praised a candidate because he often failed many of his students while his students, many of which had failed the course or got poor grades, provided highly positive anonymous feedback on his teaching at the end of their classes. This almost sadomasochistic feature of education - teacher desire to fail as many students as possible to set up the high standards and the rigor of education and the students' appreciation of the pain of being academically failed - become a hallmark of the pedagogical quality of teaching. It is important to investigate further how common the sadomasochistic attitudes among both students and teachers.

\section{Teachers' desire to avoid pedagogical violence}

Is the elimination of pedagogical violence possible and even desirable in education (what one could call a "legal argument" before a trial)? Our look at pedagogical violence is open to the accusation of "condescension" - an attitude of patronizing superiority - outlined by Worsham (1998) and Bourdieu and Passeron (1990). Efforts to minimize or eliminate pedagogical violence, for example, by effacing the hierarchical differences between teachers and students or distributing power of the curriculum across everyone in the classroom evenly, even though well-meaning, may still reproduce the dominant pedagogy of violence. For example, weakening or eliminating a vertical teacher-students hierarchy may lead to the emergence of a horizontal student-student hierarchy with not less but more violence. When in his pedagogical experiment, Lensmire weakened his teacher authority during his writer workshop in a 2nd-grade classroom, some "popular" White middle-class students created scapegoats out of their less popular minority working-class classmates to make their texts laughable for the rest of the class (Lensmire, 1994a, 1994b). Arguably, sometimes teacher-based vertical pedagogical violence rooted in hierarchy - what Graeber (2015) called "structural violence" - can be softer, more just, and less omnipresent than students-based horizontal pedagogical violence rooted in democracy.

Another possibility is the risk of "token change." With "token change," there may be nominal power over the curriculum by the students or a sense in which they can participate equally with the teacher, but the structure of the students' emotional life (such as feelings of inferiority or superiority) is such that these are felt as rare privileges, further solidifying the dominant pedagogy elsewhere in the school or teacher-control in the alternative pedagogy. For example, there is an innovative pedagogical practice of "learning contracts" (Knowles, 1986), in which students are supposed to identify the process and content of student learning with the help of the teacher: "A learning contract is a collaboratively written agreement between a student and a faculty member that delineates what is to be learned, how it will be learned, and how that learning will be evaluated"'. In our assessment, the learning contract practices are consistent with the Progressive education paradigm of manipulating an "educated subject" (Fendler, 1998), in which students are put into a position in which they acknowledge goals, values, and limitations tacitly imposed on them by teachers as their own. In essence, we argue that learning contracts create an illusion of freedom of choice and negotiability in the students, but govern them by guilt (Hargreaves, 1994) that necessarily emerges in students when they have transgressed "their own" signed contract (Matusov, von Duyke, \& Kayumova, 2016).

${ }^{9}$ http://www.wpi.edu/Academics/ATC/Collaboratory/Idea/contractbenefits.html 
Similarly, Sihra and Anderson (2010) suggest that conventional pedagogies often assume legitimate knowledge as singular and superior and violently oppose alternative perspectives. Nonetheless, Worsham (2013) would probably suggest that Sihra and Anderson's (2010) remedy "ahimsa" from Mahatma Gandhi, meaning "do no harm," may not overcome these "patterns of feeling" (e.g., of superiority/inferiority among some students and teachers) precisely because it suggests a change of orientation and attitude in an emotional field while ignoring relations of domination and subordination through historical and institutional realities or operating a pedagogy of "condescension" of assumed equality amid manifest inequality.

Similarly, other work which has attempted to reduce or efface pedagogical violence through, for instance, encouraging open democratic spaces with minimal teacher intervention or intervention to improve listening skills and humanism, while keeping alienating instrumental education in-tact, (e.g., Mokeyeva, Zakirova, \& Masalimova, 2015) falls foul of the same critique of some kind of collusion with the dominant pedagogy through promoting what could possibly end up being "token" change rather than a genuine change of heart among teachers and students alike.

Many teachers want students' submission to unconditional cooperation through voluntary means (Labaree, 2003). Students' voluntary submission involves a certain degree of negotiation between the student's and societal desires (Sidorkin, 2002, 2009). We argue that voluntary means include three major possibilities (and their mixture). First is honest persuasion when a student becomes convinced to submit his/her will for the educational unconditional cooperation by arguments. Often students are reminded of the benefits of the imposed education for their future well-being and at times about the usefulness of the imposed education for their present. When students are convinced of the benefits of education for them, they can willingly participate in the education designed for them by trusting the pedagogically unilateral decisions by the teacher. The main problem with this approach is that honest arguments are always conditional and imply a real and legitimate possibility to not cooperate if an honest argument turns the other way - otherwise, argumentation turns into manipulation abusing students' lack of certain knowledge, which Bourdeau would define as "symbolic violence" (Bourdieu \& Passeron, 1990). Also, it is difficult to engage in honest argumentation about the benefits of education with students, who are viewed as ignorant and intellectually inept by the conventional definition. Finally, if students can appreciate education via argumentative persuasion, why must they subordinate themselves to educational cooperation unconditionally?! In other words, the honest regime of argumentation and persuasion makes teacher-student cooperation conditional by default.

Second is open bribery when a student gets (or is promised to get) what she or he wants in exchange for her or his unconditional cooperation. Students' unconditional cooperation can be bribed ${ }^{10}$ by good grades, by money, and by favors valuable to the students (e.g., engaging into extracurricular activity, teacher-student meaningful socialization and friendship, field trips, extra points toward grade mark, providing extra recess time, excusing from assignments) (Sidorkin, 2002, 2009). The main problem with open bribery is that it is expensive, requiring more and more resources to give away to the student, and not reliable in the long run as the student's desires transform. Also, one common problem with these two approaches is that even when they are successful in enlisting a student's desire to unconditionally cooperate, the student may still have problems to deliver this unconditional cooperation because it may take too big toll on the students' psychological well-being and will or simply undoable for

\footnotetext{
${ }^{10}$ Sometimes, when bribes are expected, withdrawal of bribes/rewards can be perceived by a student as a punishment, which can become pedagogical violence.
} 
the student. How long can one submit $100 \%$ of her or his own will, mind, heart, desire, communication, and agency even when one tries intentionally to do that?! Total submission often breaks or severally damages the student's authorial agency on a long and may lead to addiction, depression, and/or violence (Wilensky, 1960).

The third approach is employed by Progressive Education that tries to make unconditional educational cooperation genuinely intrinsic. It involves wrapping the imposed education (but especially imposed curriculum) in learning activities that are very attractive to the student so the students cannot resist but willingly participate in them. Dewey called this process of making students engage in the society-defined curriculum "double psychologizing" (Dewey, 1956). The learning activities should be designed by educators in such a way as to generate intrinsic motivation in all students in all curriculum topics all the time by promoting excitement, curiosity, interest, fun, entertainment, collaboration, and friendship in the students. As the Progressive American educator and psychologist Bruner wrote, "...any subject could be taught to any child at any age in some form that was honest" (Bruner, 1986, p. 129). The educational imposition is wrapped in the student's choice. Young students may not want to do arithmetic drills but they may like to play video arcade games that may require these repetitive arithmetic problems as a part of the fun game. Learning becomes mostly by-productive for the students - carefully and purposefully embedded in students' games, projects, play, and other activities of the students' choice. This approach by Progressive Education is arguably manipulative. The forerunner of the Progressive education, French writer Jean-Jacques Rousseau, rather cynically placed manipulation in the heart of negotiable instruction to ensure that the societal curriculum is non-negotiably imposed on the students is acceptable and desired by them, while not being visible to them (Rousseau, 1979, p. 120).

\section{Can good education survive without pedagogical violence?}

Can institutionalized education successfully run voluntarily, -- i.e, ., when students, with or without the help of the teacher, decide whether to study, when to study, what to study, how to study, what study means for them, and with whom to study? On the one hand, we have some evidence for a positive answer to this question. Almost all children learn their native language and their many native cultural practices outside of any educational institution, arguably without pedagogical violence (Rogoff, 2003). Also, there are private democratic schools, in which academic learning is voluntary and often organized by the students themselves, that are not based on pedagogical violence (Greenberg, 1991, 1992; Neill, 1960; Rietmulder, 2009).

On the other hand, pedagogical experimentation in high education with the Open Syllabus pedagogical regime, where students choose classes (for some students and classes) and design their own education (Shor, 1996), show a complex picture (Matusov, 2015; Matusov \& Marjanovic-Shane, 2017). Some (but not all!) students in an Open Syllabus pedagogical regime (often but not always) use the class resources (the allocated time and efforts) for other demands of their life - mostly survival and necessities - even when they highly value the class for their own personal and professional growth. Below are two Open Syllabus students' unsolicited reflections on their Open Syllabus classes,

In short, I am having a terrible semester. I have bit off more than I can chew in having a part time job and taking 2 honors classes as well as extracurricular activities. When I miss class it is because I am either working extra hours at work or I am cramming for my next exam. I realize I have not been the ideal participant in our class but I can assure you I do really enjoy our EducXXX class and the topics we discuss. Urban education is a passion of mine and I looked forward to this class until I became so stressed this semester. It probably obvious to you, as well 
as to myself, that because of our open syllabus and "no grades" policy, that I have used this class as a cushion for my heavy workload. I apologize because I know I have taken advantage of what was supposed to beneficial to my learning and our class. I don't know how to make up for the class time that I have missed except to tell you that I really have enjoyed what I have been there for and that I have tried to use webtalk to understand the days I missed. I hope you see that when I am in class I enjoy participating and have a lot to offer (email [to the instructor], November, 2012) (Matusov, 2015, pp. A198-A199).

I'll say it [the Open Syllabus class] 100\% doesn't work for me and I've learned that this semester. ... I'm not a stressed out person, but I put a lot of on my plate often [including] this class clearly for me, which was a class that I was expecting to be my favorite. I mean I still love your class, but... [I was] expecting it to be ... the class I put the most effort in, because it's a topic I'm most interested in and it got completely pushed to the side for me and I [have] consciously realized that the entire semester. But also [I] just couldn't compromise my grades [in my other, non-Open Syllabus, classes] and my work... I have a job ... and my other stuff and I was like... well that's - this unfortunately is the thing that gets significant [...] and I needed that. That's awful... (Matusov \& Marjanovic-Shane, 2017, p. E12).

It seems that when the Open Syllabus pedagogical regime is embedded in the life of a student full of many concerns about survival and necessities, the student's own high commitment to his/her own highly valuable and even potentially pleasurable desire becomes weak. Self-defined education without pedagogical violence may require a different type of lifestyle that is based on leisure and not on survival or necessities (the Greek original word "school" meant "leisure"). Also, it can be that many formative years spent by the students in conventional institutions, based on non-negotiable impositions and pedagogical violence, have traumatized and suppressed students' educational agency. Some democratic educators who observed this phenomenon argue for special "school detox" or "alienation vacation" for the students, letting them doing nothing for some time before their educational agency and activism can kick on (Greenberg, 1991; Llewellyn, 1998; Matusov \& Brobst, 2013; Neill, 1960). These concerns forced my colleague and I to retreat from our pedagogical experiments into the Opening Syllabus pedagogical regime, where we start with providing only limited choices and limited decision making to our students and then gradually open the regime for more and more decision making, democratic governance, and ownership for our students. The Opening Syllabus regime is still based on pedagogical violence - teacher's unilateralism in decision making imposed on the students through threats of grade demerits at the beginning of the class - being consented by the students in the middle of the semester (unless some of them - a small minority - choose to switch to Open Syllabus) (Matusov, 2015; Matusov \& Marjanovic-Shane, 2017).

Alexander Sidorkin criticized conventional schooling for the use of a feudal regime of power based on violence to make students study - i.e., pedagogical violence ${ }^{11}$ (Sidorkin, 2002). He argues that education is primarily public, a societal endeavor to culturally and economically reproduce the society, rather than a personal endeavor of the student's self-improvement or social mobility. That is why, Sidorkin argues, student's study is a form of alienated labor that must be monetarily compensated if we, the society, want to avoid pedagogical violence as the major form of students' motivation to study. Sidorkin proposes replacing current feudal relations in education with capitalist relations.

\footnotetext{
${ }^{11}$ Although Sidorkin did not use the term "pedagogical violence" in his book - just "violence" or "school violence," in our view, he meant and described pedagogical violence.
} 
Essentially, through his policy of monetary compensation of students' studies, Sidorkin suggests replacing social pedagogical violence mostly directed by teachers with students' self-inflicted pedagogical violence. Students will be paid to force themselves to unconditionally cooperate with nonnegotiable imposition of curriculum in order to produce learning outcomes desired by the society while they can choose instruction and the rest of the pedagogical regime for themselves.

This reveals the primary source of pedagogical violence. Pedagogical violence is a natural consequence of alienated, instrumental. education. When curriculum is defined, designed, and imposed by society, pedagogical violence is unavoidable. When education is viewed as cultural reproduction i.e., training and strict socialization in targeted practices - rather than student's authorial production, pedagogical violence is unavoidable. Thus, we think that in our society based on the instrumentality of survival and necessities, pedagogical violence can be avoided in a very limited number of cases and on a limited scale in particular local relations, classrooms, and schools. We argue that pedagogical violence can be avoided only when education becomes primarily a personal voluntary endeavor of selfimprovement, self-transcendence, self-growth, and self-actualization of culture-making, rather than a societal endeavor of cultural reproduction. However, for that, society has to move from being survival and necessity-based to leisure-based living. As pointed out above, the Greek word "school" means leisure. The notion of school-as-leisure emerged in Ancient Greek slavery-based society where freefrom-labor citizens had the luxury of engaging in a special type of leisure, named education - a leisure pursuit of critical examination of life, self, world, and society (Arendt, 1958; Plato, 1997). Currently, technological advancement in robotics and artificial intelligence may create similar conditions for a labor-free society (or at least a hybrid), where genuine school-as-leisure can re-emerge (Brynjolfsson \& McAfee, 2011; Kaku, 2011, 2014; Markoff, 2015; Matusov, 2020, in press-b; Zhao, 2009). It is an interesting empirical question whether a culture of "active leisure," including leisure of genuine education, will emerge in a labor-free society on a mass scale as some scholars predict (Arendt, 1958; Gorz, 1989; Keynes, 1930/1963; Markoff, 2015; Marx, Engels, \& Pascal, 1947; Pink, 2005; Zhao, 2009) or it will continue a pattern of mass "passive leisure" (i.e., idling, rest, or passive consumption of readymade cultural activities and products).

\section{Addressing pedagogical violence: Carnivalesque authority of internally persuasive discourse}

This brings us finally to approach the question of axiology from another perspective - that of Bakhtin's dialogism (Bakhtin, 1999), interpreted here as ethics. "The Good" (education) and "The Bad" (violence) are unfinalized rather than finalized truths. Education can be bad in some cases and pedagogical violence (like any other violence) can be good in some other cases. Let us give examples of that.

Education can be bad and undesirable in some cases. For example, when a person crosses a street without watching for car traffic, the best immediate action is to pull the person physically back on the walking pavement rather than to try to educate him or her. Sometimes non-educational and/or educational instrumental goals have to take an emergency priority or even completely replace educational goals. Metaphorically speaking, at times, a teacher should prioritize safety and VIOLENTLY pull the student back to the pavement, without trying to educate the student about the danger of crossing the road without looking around. Yes, all this is true. HOWEVER, it is important to abstract the unique sphere of EDUCATION and claim that in the educational practice this sphere has to be prioritized ON AVERAGE (but not necessarily in each and every case) (Matusov \& Lemke, 2015). For example, it may be a good idea for a teacher to assume the role of a policewoman to stop immediate student-student 
bullying in order to prioritize students' well-being and peace in the classroom community. However, as an educator, the teacher has also a unique professional duty to engage the students in education about bullying.

Similarly, pedagogical violence can be good and desirable in some other cases. Important education can be painful. It can be painful physically (like in many athletic, physical education but not only), intellectually (by challenging the student's own dear ideas), ontologically (by undermining the student's being), socially (by disrupting the student's relations with relevant others), and so on. Socrates was executed for inflicting pedagogical pains on the ancient Athenian society by challenging its uncritical dominant status-quo. A colleague of mine (the first author) reported a case when some Canadian progressive educators engaged their First Nation students in a critical analysis of patriarchal and hierarchical communal relations, challenging the traditions of their home First Nation indigenous society that struggles to survive.

The issue of consent is key to understanding the complexities of carnivalesque authority. Considered in a binary way, good pedagogical violence should have consent from the students (they should give consent rather than not give it) but not necessarily from the rest of society. Of course, this consent is not always possible to secure because neither the teacher nor the student may know in advance that education may cause pain. This is consistent with Bourdieu's concept of symbolic violence. However, the teacher can communicate to the student that it is his or her right to end any pedagogical pain that he or she experiences. The student's academic freedoms to define his/her own education (Matusov \& Marjanovic-Shane, 2019) and his/her consent for a pedagogical violence may prevent the teacher's abuses of power rationalized by the benefits to the student who may be still ignorant of these benefits. In this case, pedagogical violence has to become a part of education itself - a critical examination of it.

In a non-binary sense, however, rather than stop the topic at the gates of non-consent, (e.g. tying one's identity to being "not good at math" and not wanting to upset this identity and so choosing not to consent to math class leading to a pedagogically violent response), it might be worth the attempt to dialogically de-crown this non-consent in some way; even trying to get to understand from within the resistance (including students attempting to question the teacher's resistance or each other's resistance to the curriculum - open or closed - or methods of teaching, assessment or appearance in school). Developing an "internally persuasive discourse" (Bakhtin, 1991; Matusov \& von Duyke, 2010), as a form of life, may take some time because it involves moving out of one's comfort zone and playing with a new identity (knowledge and identity inter-relate). While 'no means no' in life, in education, it is slightly different considering the large doses of regret that adults occasionally feel about their lack of interest in school, later on in life, or equally in teachers who resist curriculum innovations. There is an ethics of care towards these later selves (see Sullivan, Smith, \& Matusov, 2009 on a more in-depth exploration of the carnivalesque in education; Taylor, 1989 on the "future self").

Our emphasis on consent (to the carnivalesque) as a playful area of exploration offers a distinction to Bourdieu's concept of symbolic violence which, while useful, assumes a more binary understanding of consent (with full knowledge of violence, consent can be given or not given). Nonetheless, the ethical question remains of how playfully one can explore consent considering the asymmetry between the teachers' authority and that of the students in the class. Morson (2004) and Matusov $(2007 ; 2015)$ argue that authority in general and teacher authority in specific are necessary in the pedagogical regime of internally persuasive discourse. The teacher ought to provide the epistemological, pedagogical, organizational, and safety leadership. However, this leadership has a 
temporary but systemic character. The teacher authority jumpstarts internally persuasive discourse, in which everybody, including the teacher, is equally an ignorant learner, only to die in its intensity and then to be reborn again at its temporal exit. In our view, this rehabilitation of authority in internally persuasive discourse salvages the Bakhtinian notion of carnival from horizontal violence by peers and communal prejudices, from epistemological ignorance, and from pedagogical chaos. Thus, initially, students may accept the teacher's guidance simply because the teacher has an institutional role. However, if the teacher's guidance did not prove to be useful and appreciated by the students, this trust would be withdrawn. When the teacher engages the students into discussion, the students have to make their own mind about argumentation presented to them by the teacher, the other students, and themselves and not by the teacher's institutional or epistemological authority. Two plus two is four not because the teacher said so or because it is the correct answer for the test but because the student freely and without any manipulation comes to this conclusion him/herself assisted by the teacher, other students, and his/her own reasoning (i.e., Bakhtin's "internally persuasive discourse"). Only when the teacher proves that his or her guidance is useful for students' making their own informed mind, the teacher gets more credit and trust for his/her pedagogical, organizational, and epistemological authority. Of course, this internally persuasive discourse - a public critical dialogue - cannot be imposed on a student, who should have a legitimate choice to participate in it voluntarily and can legitimately withdraw from his/her participation in it at any time. Finally, the ideological power of critical dialogue, succinctly articulated in Plato's Apology by Socrates, "The unexamined life is not worth living" (Plato \& Riddell, 1973), has to be challenged in and out of this dialogue. Thus, as Kukathas (2003) convincingly points out with his example of a Muslim fisherman, unexamined life can be worth living while the examined life may not be worth living.

However, at its best such "internally persuasive discourse" also offers a counter-argument to Worsham (1998) and Bourdieu and Passeron (1990). For these authors, power and authority are static or reproduced inter-generationally. These structures of power/feeling may generate counter-discourses to sustain their hegemony but this hegemony itself is non-generative and unchanging. Our conception of "temporary and systemic" authority/power is regenerative. It is regenerative because Bakhtin's "internally persuasive discourse" can shape power/authority, not just in an intellectual way, but in a carnivalesque, participatory fashion. The threat of carnivalesque violence and chaos demands modification in the order of things - as hegemony is "grounded" or "accentuated" by participatory inquiry. Carnival admits to the possibility of "condescension" as a temporary horizontalization of power rather than as a self-deceptive power-grab. All alternative wrong and "stupid" ideas become important building blocks for truth. One cannot fully understand why $2+2$ is 4 until one considers other possibilities, why they are wrong, and limitations of its truthfulness (e.g., two friends plus two friends does not necessarily result in four friends). "De-crowning" what we hold dear - our interests, our identity, our communal values, our habits of thinking, - does not need to be violently painful; there is potential for it to be painfully joyful (cf. "laughing until stomach pain"), when participants interested in and value it.

We acknowledge that education cannot be completely painless. Physical and psychosocial pain can be intrinsic to some type of learning. Pain and violence can be also intrinsic to instruction and a life of learning community (Matusov \& Marjanovic-Shane, 2015). This kind of axiological position leads to a complicated ethics around pain and violence in education - one where violence climbs down from a zone of Plato's transcendent instrumentality (e.g., rules) to a zone of particularity - where acts are 
authored by those with "a non-alibi in being" (Bakhtin, 1993) who are responsible in the ethical enterprise of developing an internally-persuasive discourse, in which these ethical deeds are challenged.

However, we argue that pain and violence in conventional education are not equal to pedagogically imposed violence because pedagogical violence is aimed at ensuring the student's unconditional and total cooperation with the teacher's, school's, and society's pedagogical demands to produce the learning outcomes, desired and preset by the society. Education as internally persuasive discourse does not involve this unconditional cooperation and curricular endpoints preset by the society. The pedagogical regime of internally persuasive discourse is democratic, voluntary, and open for the students' input, ownership, negotiation, and legitimate freedom of non-guilty divorce and nonparticipation. Finally, emerging pains and violence in education are humanized in dialogue of collective meaning-making and democratic decision making (Matusov \& Marjanovic-Shane, 2015).

\section{Conclusions: What can we do with pedagogical violence?}

We define pedagogical violence as inflicting physical or psychosocial pains on students in order to ensure their unconditional cooperation with the pedagogical regime unilaterally imposed by teachers, school and society. Secondary pedagogical violence also includes inflicting pains in response or in resistance or as a by-product of the primary pedagogical violence. Pedagogical violence can be initiated by teachers, school administrators, police, students, and parents. Pedagogical violence can occur outside of school, for example, at home. It involves violence to promote or result from the imposition of pedagogical processes desired by the authority. However, pedagogical violence does not include pains and discomforts that may be intrinsic to learning itself.

We have identified the main cause of pedagogical violence in the instrumental, reproductive, and impositional nature of modern mass education and even some innovative education. When education is not initiated by, consented with, and democratically dialogically negotiated with the students, learning becomes alienated. Alienated learning creates conditions and necessities for pedagogical violence. When curriculum (what to study) and education (whether to study) are defined, designed, and imposed by society on the students, pedagogical violence unavoidably becomes a tool of this imposition.

We have abstracted several current approaches to pedagogical violence:

1. Softening, humanizing, and minimizing pedagogical violence

In accordance with Foucault's (1995) observation, schools have been moving from physical to psychosocial pedagogical violence. Although Foucault challenged the idea that psychosocial violence is "softer" and "more humane" than physical violence, this seems to be the dominant view, at least among the middle-class mainstream. Physical discipline and punishment of children as such by parents, schools, and strangers become more and more associated with abuse, while psychosocial discipline of mind is not necessarily ${ }^{12}$.

Nevertheless, there have been growing voices to minimize psychosocial violence associated with suspensions, detentions, and expulsions to what is minimally necessary. The disproportional application of pedagogical violence to particular social groups like minorities (especially for African American males in the US), working-class, and males raises issues of how much pedagogical violence services other functions such as domestication and colonization of these groups by feminized white middle-class

\footnotetext{
${ }^{12}$ At the same time there is a counter-current of nostalgia for a physical punishment, with "a personal and caring touch" - i.e., so-called "tough love," - over cold, calculative, and often irresponsible bureaucratic psychosocial punishments of "managing populous." This sentiment can be found in Foucault (1995).
} 
ideologies (Kupchik, 2016). Yet, in our view, this approach does not try to address the root of the problem, namely alienated, instrumental, reproductive, imposed education, and its view of violence is too static - not considering the possibility of "cyclical" pedagogical violence.

2. Replacing pedagogical violence with pedagogical manipulation

Progressive education offers another solution for pedagogical violence. It tells us to find ways to engage students in the curriculum preset by society. In essence, progressive education wishes to develop ways to make the student genuinely want to study what the society wants the student to study - using a Foucaultian term, to create "the educated subject" (Fendler, 1998). In our view, this move involves the replacement of pedagogical violence with pedagogical manipulation of the student's subjectivity for the student to unconditionally accept the present societal curriculum. The students' background, interests, home culture are exploited to teach the preset societal curriculum, which may remain deeply irrelevant for the student. We agree with Sidorkin $(2002,2009)$ that this pedagogical manipulation cannot be always successful - it cannot work for every student in every circumstance with every preset societal curriculum. Thus, progressive education always incorporates pedagogical violence and cannot avoid it entirely if the curriculum and education itself are unconditionally imposed on the students.

\section{Internalization of pedagogical violence}

Sidorkin $(2002,2009)$ and some other educators propose to pay students for their alienated studies, required by the society for its cultural, social, economic, and political reproduction, like workers are paid for their alienated labor, required by the economy (and capitalists). Thus, feudal relations of violence, on which many conventional and innovative schools are based, should be replaced by capitalist relations of contractual monetary compensations. In our view, this proposal does not eliminate pedagogical violence but transforms it from social and relational to internalized and self-inflicted. Like the three previous proposals, this proposal does not eliminate the main conditions for pedagogical violence but rather softens, minimizes, and curbs it, which, in our view, is a nontrivial achievement.

\section{Student academic pedagogical rights movement}

Emerging from the college students' protests of the Civil Rights movements in the 1960s in the US and elsewhere (AAUP, 1968), there has been growing interest in development of the Student Rights, especially in higher education ${ }^{13}$. Often the student rights are focused on curbing pedagogical violence, like for example, the right to protection from discrimination, or the right to protection from verbal or written abuse (AAUP, 1968). Students' freedoms and rights usually were defined holistically (e.g., freedom of assembly, religion, expression) and there was little attention to pedagogical academic aspects of the student life. However, recently, the student rights movement has started challenging many academic pedagogical practices of alienated education (Marjanovic-Shane \& Matusov, 2017, February), such as summative assessment, redefined as illegitimate and violent "pedagogical voyeurism" (Matusov, Marjanovic-Shane, et al., 2016) or "the surveillance of learning" (Macfarlane, 2013), and preset curriculum, unilaterally defined and designed by the teachers, schools, and society (Greenberg, 1992; Matusov, 2015; Neill, 1960). In our view, the student academic pedagogical rights movement pushes for the total transformation of education that we discuss in the next section (Matusov \& Marjanovic-Shane, 2019). Arguably, it does this through an exercise in practical imagination (Graeber, 2015) where the impossible is suddenly possible. However, this carries with it the risk of a reorganization of bureaucracy (and the violence that goes with enforcing it - a too often tragic

\footnotetext{
${ }^{13}$ See, https://en.wikipedia.org/wiki/Student rights in higher education.
} 
consequence of revolutions). In our final section, we discuss the relevance of cycles of carnivalesque authority of internally persuasive discourse to this issue.

\section{Carnivalesque authority of internally persuasive discourse}

Some democratic dialogic educators (Matusov, 2007, 2009; Matusov \& Marjanovic-Shane, 2012; Morson, 2004; Sullivan, et al., 2009) propose the pedagogical regime of "internally persuasive discourse" (Bakhtin, 1991; Matusov \& von Duyke, 2010), in which "truth becomes dialogically tested and forever testable" (Morson, 2004, p. 319) as an alternative to pedagogical violence. Students are invited to democratically define and negotiate their curriculum (Matusov, 2015). However, as Morson (2004) and Matusov (Matusov, 2007; Matusov \& Marjanovic-Shane, 2015) show education based on the pedagogical regime of internally persuasive discourse cannot be sustained without the teacher authority that provides epistemological, pedagogical, and organizational leadership, the (un)usefulness of which is evaluated and judged by the students. This leadership goes through the cycle of birth, death, and rebirth - carnivalesque crowning and decrowning the teacher authority - in internally persuasive discourse. As we discussed above, this process may not be completely painless but this pain, like pain that maybe inherent in some particular learning, stops being pedagogical pain because it is not aimed at ensuring the students' unconditional cooperation with the teacher's demands but is based on ethical responsivity. However, in our view, education, defined as internally persuasive discourse, cannot be possible on a large scale in a society based on labor and work of people acting as smart machines (Arendt, 1958; Ford, 2015; Markoff, 2015; Mitra, 2013).

We welcome all five approaches to softening, humanizing, curbing, replacing or eliminating pedagogical violence. However, we believe that unless alienated, instrumental, reproductive, societal, imposed education will be replaced with intrinsic, critical, productive, ontological, personal, and voluntary education, the conditions for pedagogical violence will remain. Unfortunately, the latter type of education cannot flourish in a society based on the survival, necessities, and labor/work of people acting like smart machines. Fortunately, technological advances may create conditions for a leisurebased (or at least hybrid) society, in which personal intrinsic education of leisurely pursuit of critical examination of the self, life, world, and society will become possible on a mass scale.

\section{References}

AAUP. (1968). Joint statement on rights and freedoms of students. AAUP Bulletin, 54(2), 258-261. Arendt, H. (1958). The human condition. Chicago: University of Chicago Press.

Bakhtin, M. M. (1984). Rabelais and his world (H. Iswolsky, Trans. 1st Midland book ed.). Bloomington: Indiana University Press.

Bakhtin, M. M. (1991). The dialogic imagination: Four essays by M. M. Bakhtin (C. Emerson \& M. Holquist, Trans.). Austin, TX: University of Texas Press.

Bakhtin, M. M. (1993). Toward a philosophy of the act (V. Liapunov, Trans. 1st ed.). Austin: University of Texas Press.

Bakhtin, M. M. (1999). Problems of Dostoevsky's poetics. Minneapolis: University of Minnesota Press. Bellow, S. (1996). Henderson, the rain king. New York: Pengiun Books.

Bourdieu, P., \& Nice, R. (2001). Masculine domination. Cambridge: Polity.

Bourdieu, P., \& Passeron, J. C. (1990). Reproduction in education, society, and culture. London: Sage. Bourdieu, P., \& Wacquant, L. c. J. D. (1992). An invitation to reflexive sociology. Cambridge: Polity. Bruner, J. (1986). Actual minds, possible words. Cambridge, MA: Harvard University Press. Brynjolfsson, E., \& McAfee, A. (2011). Race against the machine: How the digital revolution is accelerating innovation, driving productivity, and irreversibly transforming employment and the economy: Digital Frontier Press. 
DePalma, R., Matusov, E., \& Smith, M. P. (2009). Smuggling authentic learning into the school context: Transitioning from an innovative elementary to a conventional high school. Teacher College Record, 111(4), 934-972.

Dewey, J. (1956). The child and the curriculum and the school and society (Combined ed.). Chicago: University of Chicago Press.

Eckert, P. (1989). Jocks and burnouts: Social categories and identity in the high school. New York: Teachers College Press.

Eisenberger, N. I., \& Lieberman, M. D. (2004). Why rejection hurts: A common neural alarm system for physical and social pain. Trends in cognitive sciences, 8(7), 294-300.

Eisenhart, M., \& Allen, C. D. (2016). Hollowed out: Meaning and authoring of high school math and science identities in the context of neoliberal reform. Mind, Culture, and Activity, 23(3), 188-198.

Fendler, L. (1998). What is it impossible to think? A genealogy of the educated subject. In T. S. Popkewitz \& M. Brennan (Eds.), Foucault's challenge: Discourse, knowledge, and power in education (pp. 39-63). New York: Teachers College Press.

Ford, M. (2015). Rise of the robots: Technology and the threat of a jobless future. New York: Basic Books.

Fordham, S., \& Ogbu, J. U. (1986). Black students' school success: Coping with the "burden of acting White.". Urban Review, 18(3), 176-206.

Foucault, M. (1983). Afterword: The subject and power. In H. L. Dreyfus, P. Rabinow \& M. Foucault (Eds.), Michel Foucault: Beyond structuralism and hermeneutics (2nd ed., pp. 208-226). Chicago: University of Chicago Press.

Foucault, M. (1995). Discipline and punish: The birth of the prison (2nd Vintage Books ed.). New York: Vintage Books.

Freire, P., Freire, A. M. A. j., \& Freire, P. (1994). Pedagogy of hope: Reliving Pedagogy of the oppressed. New York: Continuum.

Garbutt, J., Brownstein, D. R., Klein, E. J., Waterman, A., Krauss, M. J., Marcuse, E. K., et al. (2007). Reporting and disclosing medical errors: pediatricians' attitudes and behaviors. Archives of pediatrics \& adolescent medicine, 161(2), 179-185.

Gorz, A. (1989). Critique of economic reason (G. Handyside \& C. Turner, Trans.). London: Verso.

Graeber, D. (2013). The Democracy Project: A history, a crisis, a movement (1st ed.). New York: Spiegel \& Grau.

Graeber, D. (2015). The utopia of rules: On technology, stupidity, and the secret joys of bureaucracy. Brooklyn London: Melville House.

Greenberg, D. (1991). Free at last: The Sudbury Valley School. Framingham, MA: Sudbury Valley School Press.

Greenberg, D. (1992). The Sudbury Valley School experience. Framingham, MA: Sudbury Valley School Press. Retrieved from http://www.sudval.com/05 underlyingideas.html\#05.

Groys, B. (2017). Between Stalin and Dionysus: Bakhtin's theory of the carnival. Dialogic Pedagogy: An International Online Journal, 5, DB:1-DB:5, doi: 10.5195/dpj.2017.212. Retrieved from http://dpj.pitt.edu/ojs/index.php/dpj1/article/view/212/158.

Hargreaves, A. (1994). Changing teachers, changing times: Teachers' work and culture in the postmodern age. London: Cassell.

Infinito, J. (2003). Jane Elliot meets Foucault: The formation of ethical identities in the classroom. Journal of Moral Education, 32(1), 67-76.

Jackson, P. W. (1968). Life in classrooms. New York: Holt Rinehart and Winston.

Kaku, M. (2011). Physics of the future: How science will shape human destiny and our daily lives by the year 2100 (1st ed.). New York: Doubleday.

Kaku, M. (2014). The future of the mind: The scientific quest to understand, enhance, and empower the mind (First edition. ed.). New York: Doubleday. 
Keynes, J. M. (1930/1963). Economic possibilities for our grandchildren. In J. M. Keynes (Ed.), Essays in persuasion (pp. 358-373). New York: Norton.

Knowles, M. S. (1986). Using learning contracts (1st ed.). San Francisco: Jossey-Bass.

Kukathas, C. (2003). The liberal archipelago: A theory of diversity and freedom. Oxford: Oxford University Press.

Kupchik, A. (2016). The real school safety problem: The long-term consequences of harsh school punishment. Oakland, California: University of California Press.

Labaree, D. F. (2003). The peculiar problems of preparing educational researchers. Educational Researcher, 32(4), 13-22.

Lareau, A. (2003). Unequal childhoods: Class, race, and family life. Berkeley: University of California Press.

Lensmire, T. J. (1994a). When children write: Critical re-visions of the writing workshop. New York: Teacher College Press.

Lensmire, T. J. (1994b). Writing workshop as carnival: Reflections on an alternative learning environment. Harvard Educational Review, 64(4), 371-391.

Llewellyn, G. (1998). The teenage liberation handbook: How to quit school and get a real life and education (Rev., 2nd ed ed.). Eugene, OR: Lowry House.

Lukianoff, G. (2013). Unlearning Liberty: Campus censorship and the end of American debate: Encounter Books.

Macfarlane, B. (2013). The surveillance of learning: A critical analysis of university attendance policies. Higher Education Quarterly, 67(4), 358-373.

Marjanovic-Shane, A., \& Matusov, E. (2017, February). Students' perceptions of their academic pedagogical freedoms and rights. Paper presented at the 38th Annual Ethnography in Education Research Forum, Philadelphia, PA.

Markoff, J. (2015). Machines of loving grace: The quest for common ground between humans and robots. New York: HarperCollins.

Marx, K., Engels, F., \& Pascal, R. (1947). The German ideology. New York: Interntaional Publishers.

Matusov, E. (2007). Applying Bakhtin scholarship on discourse in education: A critical review essay. Educational Theory, 57(2), 215-237, doi: 10.1111/j.1741-5446.2007.00253.x.

Matusov, E. (2009). Journey into dialogic pedagogy. Hauppauge, NY: Nova Science Publishers.

Matusov, E. (2015). Legitimacy of non-negotiable imposition in diverse approaches to education. Dialogic Pedagogy: An International Online Journal, 3, A174-A211. Retrieved from http://dpj.pitt.edu/ojs/index.php/dpj1/article/view/110/105.

Matusov, E. (2020, in press-a). Dialogic analysis of the teacher's pedagogical decision-making in a lesson on the educational controversies of religious holidays in a dialogic multi-regime college classroom. In M. C. Oliveira, A. U. Branco \& S. F. Freire (Eds.), Psychology as a Dialogical Science: Self and culture mutual development. New York: Springer.

Matusov, E. (2020, in press-b). Envisioning education in a post-work society: A dialogic perspective. New York: Palgrave.

Matusov, E., Baker, D., Fan, Y., Choi, H. J., \& Hampel, R. L. (2017). Magic Learning Pill: Ontological and instrumental learning in order to speed up education. Integrative Psychological and Behavioral Science, 51(3), 456-476, doi: 10.1007/s12124-017-9384-8.

Matusov, E., \& Brobst, J. (2013). Radical experiment in dialogic pedagogy in higher education and its centaur failure: Chronotopic analysis. Hauppauge, NY: Nova Science Publishers.

Matusov, E., \& Lemke, J. L. (2015). Values in dialogic pedagogy (Editorial). Dialogic Pedagogy: An International Online Journal, 3, E1-E20, doi: 0.5195/dpj.2015.141. 
Matusov, E., \& Marjanovic-Shane, A. (2012). Diverse approaches to education: Alienated learning, closed and open participatory socialization, and critical dialogue. Human Development, 55(3), 159-166, doi: 10.1159/000339594.

Matusov, E., \& Marjanovic-Shane, A. (2015). Rehabilitation of power in Democratic Dialogic Education. In K. Jezierska \& L. Koczanowicz (Eds.), Democracy in dialogue, dialogue in democracy (pp. 193209). Farnham, UK: Ashgate Publishing Ltd.

Matusov, E., \& Marjanovic-Shane, A. (2017). Promoting students' ownership of their own education through critical dialogue and democratic self-governance (Editorial). Dialogic Pedagogy: An International Online Journal, 5, E1-E29, doi: 10.5195/dpj.2017.199. Retrieved from https://dpj.pitt.edu/ojs/index.php/dpj1/article/view/199.

Matusov, E., \& Marjanovic-Shane, A. (2019). Intrinsic education and its discontents. In L. Tateo (Ed.), Educational dilemmas: A cultural psychological perspective (pp. 21-40). New York: Routledge.

Matusov, E., Marjanovic-Shane, A., \& Gradovski, M. (2019). Dialogic pedagogy and polyphonic research art: Bakhtin by and for educators, doi: 10.1057/978-1-137-58057-3. New York: Palgrave Macmillan.

Matusov, E., Marjanovic-Shane, A., \& Meacham, S. (2016). Pedagogical voyeurism: Dialogic critique of documentation and assessment of learning. International Journal of Educational Psychology, 5(1), 1-26, doi: 10.17583/ijep.2016.1886. Retrieved from http://hipatiapress.com/hpjournals/index.php/ijep/article/view/1886/pdf.

Matusov, E., \& von Duyke, K. (2010). Bakhtin's notion of the Internally Persuasive Discourse in education: Internal to what? (A case of discussion of issues of foul language in teacher education). In K. Junefelt \& P. Nordin (Eds.), Proceedings from the Second International Interdisciplinary Conference on perspectives and limits of dialogism in Mikhail Bakhtin Stockholm University, Sweden June 3-5, 2009 (pp. 174-199). Stockholm: Stockholm University.

Matusov, E., von Duyke, K., \& Kayumova, S. (2016). Mapping concepts of agency in educational contexts. Integrative Psychological and Behavioral Science, 50(3), 420-446, doi: 10.1007/s12124-0159334-2.

McLaren, P. (1993). Schooling as a ritual performance: Towards a political economy of educational symbols and gestures (2nd ed.). London; New York: Routledge.

McNeil, L. M. (1986). Contradictions of control: School structure and school knowledge. New York: Routledge \& K. Paul.

Mitra, S. (2013). Build a school in the cloud. Retrieved from http://www.ted.com/talks/sugata mitra build a school in the cloud.

Mokeyeva, E. V., Zakirova, V. G., \& Masalimova, A. R. (2015). Tolerant pedagogic space as a condition of non-violence position education among elementary school pupils. Review of European Studies, 7(4), 216.

Monk, R. (1996). Bertrand Russell: The spirit of solitude, 1872-1921. New York: Free Press.

Moore, M. (2009). On the roots of teaching and learning. ETC: A Review of General Semantics 66(4), 422 428.

Morson, G. S. (2004). The process of ideological becoming. In A. F. Ball \& S. W. Freedman (Eds.), Bakhtinian perspectives on language, literacy, and learning (pp. 317-331), doi: 10.1017/СВ09780511755002.016. Cambridge, UK; New York: Cambridge University Press.

Mouffe, C. (2000). The democratic paradox. London: Verso.

Neill, A. S. (1960). Summerhill: A radical approach to child rearing. New York: Hart Publishing Company.

Pink, D. H. (2005). A whole new mind: Moving from the information age to the conceptual age. New York: Riverhead Books.

Plato. (1997). Complete works (J. M. Cooper \& D. S. Hutchinson, Trans.). Indianapolis, IN: Hackett Pub. 
Plato, \& Jowett, B. (1937). The dialogues of Plato. New York,: Random House. Retrieved from http://classics.mit.edu/Plato/meno.html.

Plato, \& Riddell, J. (1973). The Apology of Plato, with a revised text and English notes, and a digest of Platonic idioms. New York: Arno Press.

Ricœur, P. (1975). Violence and language Political and social essays (pp. 88-101). Athens: Ohio University Press.

Rietmulder, J. (2009). The Circle School: An introduction to integral education ideas and practices. Harrisburg PA: The Circle School.

Rogoff, B. (2003). The cultural nature of human development. New York: Oxford University Press.

Rousseau, J. J. (1979). Emile: or, On education. New York: Basic Books.

Salisbury, E. (2004). Spare the rod and spoil the child": Proverbial speech acts, boy bishop sermons, and pedagogical violence. In G. Donavin, C. J. Nederman \& R. J. Utz (Eds.), Speculum sermonis: Interdisciplinary reflections on the medieval sermon (pp. 141-155). Turnhout, Belgium: Brepols.

Shor, I. (1996). When students have power: Negotiating authority in a critical pedagogy. Chicago: University of Chicago Press.

Shulevitz, J. (2015, March 15). In college and hiding from scary ideas. The New York Times. Retrieved from http://www.nytimes.com/2015/03/22/opinion/sunday/judith-shulevitz-hiding-from-scaryideas.html? $r=0$.

Sidorkin, A. M. (2002). Learning relations: Impure education, deschooled schools, \& dialogue with evil. New York: P. Lang.

Sidorkin, A. M. (2009). Labor of learning: Market and the next generation of education reform. Rotterdam, the Netherlands: Sense Publishers.

Sihra, K., \& Anderson, H. M. (2010). Exploring pedagogical possibilities for a nonviolent consciousness. In D. Kerdeman (Ed.), Philosophy of Education 2009 (pp. 379-387) Retrieved from http://ojs.ed.uiuc.edu/index.php/pes/article/view/2732/1060.

Solloway, S. G., \& Brooks, N. J. (2004). Philosophical hermeneutics and assessment: Discussions of assessment for the sake of wholeness. Journal of Thought, 39(2), 43-60.

Sorokin, P. A. (1927). Social mobility. New York: Harper \& Brothers.

Stojnov, D., Dzinovic, V., \& Pavlovic, J. (2008). Kelly meets Foucault: Understanding school underachievement. Journal of Constructivist Psychology, 21(1), 43-59.

Strawser, M. (2009). Assessing assessment: Toward a hermeneutic-phenomenological perspective. InSight: A Journal of Scholarly Teaching, 4, 56-68.

Sullivan, P., Smith, M. P., \& Matusov, E. (2009). Bakhtin, Socrates and the carnivalesque in education. New Ideas in Psychology, 27(3), 326-342, doi: http://dx.doi.org/10.1016/j.newideapsych.2008.12.001.

Taylor, C. (1989). Sources of the self: The making of the modern identity. Cambridge, MA: Harvard University Press.

Varenne, H., \& McDermott, R. P. (1998). Successful failure: The school America builds. Boulder, CO: Westview Press.

Wilensky, H. L. (1960). Work, careers and social integration. International Social Science Journal, 12(4), 543-560.

Willis, P. E. (1981). Learning to labor: How working class kids get working class jobs (Morningside ed.). New York: Columbia University Press.

Worsham, L. (1998). Going postal: Pedagogic violence and the schooling of emotion. Journal of Advanced Composition, 18(2), 213-245.

Zhao, Y. (2009). Catching up or leading the way: American education in the age of globalization. Alexandria, VA: ASCD. 